\title{
KLHL6 wt Allele
}

National Cancer Institute

\section{Source}

National Cancer Institute. KLHL6 wt Allele. NCI Thesaurus. Code C99603.

Human KLHL6 wild-type allele is located in the vicinity of $3 q 27.3$ and is approximately 68 $\mathrm{kb}$ in length. This allele, which encodes kelch-like protein 6, may play a role in B-cell signaling. 